\title{
Dis(appearance): Earth, Ethics and Apparently (In)Significant Others
}

\author{
Mick Smith
}

In a recent presidential address to the British Ecological Society, Alastair Fitter discusses the overlooked and poorly understood ecology of soil organisms. 'Soils', he says, 'are believed to be exceptionally biodiverse parts of ecosystems' (231) and yet we actually have very little idea of just how diverse they may be, or what ecological roles this diversity plays. A recent intensive study of what is now 'probably the world's best-known soil' (240) at Sourhope in Scotland, an unexceptional site 'deliberately chosen [as part of the UK's recent Soil Biodiversity Programme] to be biologically dull' (233) still managed to identify 140 species of nematode worms and estimated the actual number to be at least 400. To put this latter figure in context, this would be more than the total number of nematode species previously identified in the whole of the UK. Prokaryotes (single-celled microbes lacking a nucleus, including bacteria) are thought to be especially diverse. This single site is estimated to contain at least half a million 'species' of bacteria - bearing in mind that we face the additional problem here of even defining what might constitute a bacterial 'species' or qualify as an equivalent taxonomical unit. And then, of course, there are the soil mites, vascular plant roots, algae, insects, fungi, earthworms, mammals, and so on, all inhabiting, creating and consuming aspects of this complex matrix of soil particles, decaying organic matter and aqueous solutions.

All this is, quite literally, the earth on which we walk, and yet our ignorance of the diverse beings that compose it is astonishing - all the more so when one considers the fundamental role soils play in human life and social history. All agriculture is dependent upon soil; every terrestrial crop we grow, harvest or collect requires it. Incredible varieties of social and cultural forms have evolved through humans' diverse relations to soil and crops - and have suffered where they over-exploit it, as Edward Hyams' classic Soil and Civilisation recounts. Ponting's Green History of the World too notes how unsuitable irrigation practices eventually caused the salinisation of soils that played a key part in the downfall of ancient Sumerian civilisation. More recently, the consequences of human-induced soil erosion were made spectacularly evident in the vast clouds of loose topsoil that blew across the U.S. Midwest during the 1930's Dust Bowl (Worster). To date, Fitter estimates, we have lost the global equivalent of $10 \mathrm{~cm}$ of cultivated soil. It seems, he says, that 'our species' blithe disregard for soil is evidence of our reluctance to understand its fundamental role in our welfare' (232). 
Of course, not every member of 'our species' is equally culpable in this respect, and the degree and kinds of attention we pay to soil varies widely within and across cultures. Subsistence and small scale agriculturalists, unlike those promoting capital intensive industrial agriculture, are well aware of soil's importance in sustaining human lives and communities (Jackson et al.). Some have gone further and suggested not only that we should pay due regard to soils in order to protect human interests but might also think about developing an environmental ethic that would enlarge the boundary of our ethical 'community to include soils, waters, plants and animals, or collectively, the land' (Leopold 204; Callicott).

But here too ignorance seemingly threatens to undermine attempts to concern ourselves with the ecology of soils and those beings that compose them. Fitter points out that 'For any other group of organisms, these questions [about soil biodiversity] would be of active concern to conservation biologists: For example, we do not know whether there are such things as rare microbial species' or whether 'there must be some endangered species of microbe, maybe even extinct species. At present, lists of known extinctions include no microbes (the smallpox virus being a possible exception), but it seems unlikely that their absence reflects anything beyond our ignorance' (234; my emphasis). Many soilinhabiting species are almost certainly becoming extinct before we even learn of their existence.

There are many contributing factors to this ignorance, most obviously the size of most of the organisms concerned. Before the development of microscopy the very existence of such beings was hardly suspected. 'Even though the earliest microscopes [such as those employed by Anton van Leeuwenhoek (1632-1723)] permitted only a tenfold magnification, this was sufficient', says Mayr, 'to reveal the existence of an entirely unexpected living microcosmos, particularly of aquatic organisms invisible to the naked eye' (100). But if microscopy made a new aqueous world transparent then the opacity of soil has also been only one of a number of additional problems faced by those trying to make such species visible and knowable. Soil is by its nature a refractive medium; it resists the analysis of its complex components. Even to identify many species they first need to be extracted from the soil matrix, isolated, and cultured in artificial media, and many simply cannot be so cultured.

What is more the 'individuals' constituting the soil community are not isolable in other senses, including their intimate inter-dependencies on each other, exemplified by the symbiotic relations between fungal mycorrhizas of the phylum Glomeromycota and plant roots. These branching networks of microscopic hyphal strands develop arborescent (or tree like) structures within plant root cells that provide phosphates essential to the plant's growth. Meanwhile, the fungi receive carbon fixed by the plant during photosynthesis. 
Like all fungi the Glomeromycota do not possess the ability to photosynthesise, and indeed this particular group seems entirely dependent upon this symbiotic relation, as they are never found in isolation. This intimate form of 'mutual aid', to use a term employed by the anarchist and early 'bio-geographer' Kropotkin, evolved more than 400 million years ago. We know this because the fossils of the earliest land plants already have arbuscules. Indeed, Fitter suggests, such relations may have been essential to plants' ability to move from their original aqueous environments onto the land where phosphate uptake was much more problematic.

We thus face a situation where the lack of attention to soil communities coincides with an ignorance also partly explained by many geological, ecological and evolutionary factors, conspiring together to make the actual members of these communities largely invisible. And to the extent that they do not appear as constituents of our world it might seem impossible to concern ourselves with them instrumentally, let alone ethically. And this raises a number of much more general questions about how and why certain Others might become ethically significant to us while others do not; about who or what 'appears' (in both the sense of 'manifesting itself' and 'seeming to matter') to share the world in ways that call forth our concern. What can we say about those beings that pass us by unnoticed, that appear only fleetingly if at all in our lives, that are invisible to the naked eye, or even those whose existence (like so many unremarked species) we are not even aware of? What could it possibly mean for such beings to 'disappear' from the world in the sense of becoming extinct when they don't appear (to be/as) significant? What, if anything, could it mean to love or conserve such beings?

\section{The Scope of Environmental Ethics}

Let us assume that ethics constitutes a non-instrumental relation of concern for those significant Others who appear to share the world with us in so very many irreducibly different ways. Environmental ethics, which seeks both to express and inform our experiences of this more-than-human world, suggests that such concerns might include a wide variety of the world's inhabitants, not just our family members, our fellow citizens, or even just other human beings, but members of other animal species, plants, fungi, or categories of other beings, like 'species', or 'things' like rock formations and streams and complex entities like forests and soils.

But how and why do some of these entities appear ethically significant? A closely related question is whether, as speaking of an entity's appearance might suggest, such recognition is primarily a matter of phenomenology, of having actually experienced (in terms of encountering, sensing and feeling) the incipient Other's 
presence in the world in a way that elicits a concerned response, or whether one can assume such responsibilities vicariously either via some form of association or by following the lines of a formal moral logic. Emphasising the way that appearance as such elicits ethical concerns recognises the importance of our emotional and valuational involvement but might seem to leave little scope for ethical engagement with beings, like those of soil communities, that remain 'invisible' or indeed with anything that falls outside the realm of personal experience. On the other hand, while a formal moral logic offers a supposedly impersonal, abstract, and context-free mode of expanding moral horizons, and to this extent might be much less reliant on the phenomenal appearance of beings as such, it thereby alters the very nature of ethics, subsuming intensely felt experiences under cognitively constructed systems.

The differences between these phenomenological and formal understandings of ethics are crucial since I want to argue very strongly for an approach (grounded in the phenomenological insights of Max Scheler, Emmanuel Levinas and Martin Heidegger) that makes ethical appearance its key feature. As such, and before we can even begin to deal with the ethics of 'non-appearance' or the other difficulties that soil organisms present, we need to consider rather more 'obvious' ethical encounters where appearance is not an issue (always bearing in mind that attending to the phenomenology of even the simplest ethical experience still presents a potentially infinite task). To this end we might begin by considering the appearance of a macroscopic, relatively familiar, easily individuated being in an open (and relatively soil-free) environment.

Imagine a photograph of a seal pup lying on an already bloody ice floe a moment before a sealer's club will strike down upon his upraised head. The appearance of this seal's situation calls forth a passionate involvement, an emotional (and ethical) concern in many people, no matter how distant they may actually be in time and space. Of course the degrees to which people are affected will vary. Some, including the sealers and the Canadian politicians who depend on their votes, may be inured to, or even revel in, this 'slaughter'. ${ }^{1}$ But the fact that the Canadian government finds it necessary to pass laws specifically forbidding the filming of the slaughter confirms that many people are indeed disturbed, appalled and angered by such images, and not because this is a wasteful use of 'resources' but precisely because the seal pup appearsas an ethically significant Other.

If we accept that it is the phenomenology of the seal's appearance (given, of course, certain hermeneutic contexts that facilitate particular understandings of that appearance - the bloody ice-floe, its photographic mediation, the

1 As Cameron remarks, this 'can't be called a hunt', since it 'is comparable to killing kittens with claw hammers' (Cameron qtd in Mowat 382). 
historically effected consciousness ${ }^{2}$ of the observer, and so on) that gives rise to these ethical concerns, then one might think that ethics would remain tied to phenomenology in the sense that one could only experience ethical concern for those individual beings that have on some occasion and in some way appeared before one. But a moment's reflection makes this seem very unlikely. For though we may indeed be moved to ethical concern by and on behalf of a particular being appearing within the context of a particular event, the ethical concern generated rarely, if ever, remains so contained. The value-feelings evoked by an image of a starving child easily bleed into a wider condemnation of situations where militarism and ethnic conflict combine to threaten entire populations. Similarly, for those of us so inclined, the single seal which appears in what is, after all, only a photograph, also elicits concerns for a much wider constituency of beings many of whom we will never encounter on film, still less 'in the flesh'.

Of course, the phenomenological 'appearance' of these broader constituencies, their felt presence, is often radically different. The intentionality of such valuefeelings is much less individually focused, less dependent upon our seeing or encountering those concerned, and correspondingly more imaginatively attenuated, although they are not necessarily less affective or persistent for that: being unable to save the actual seal pictured, we might still find ourselves campaigning against industrialized seal slaughter, to conserve marine mammals like whales, or concern ourselves with the destructive exploitation of marine environments in general. And the scope of these wider ethical constituencies is usually not easy to predict and define because they are caught up with the multiplicity of ways in which the world we inhabit is already profoundly patterned with significance and significant associations that are sometimes more, sometimes less, personal and context dependent. Ethical feelings and evaluations, we might say, overflow along already partially pre-figured, although by no means fixed, channels of significance, like running water percolating through and shifting the matrix of sea ice or rocky soils. In this ecological case the ethical constituency could well include thousands of similarly situated seals or members of other quite different species and/or even permeate our felt understandings of the ecology of the entire planet. One might say that while one's heart initially goes out to the individual seal in the photograph, what Scheler would refer to as this (positive) instance of 'fellow feeling' (Fellow Feeling 69) almost inevitablyinduces and inspires much broader concerns. ${ }^{3}$

2 Historically effected consciousness (wirkungsgeschichtliches Bewusstsein) is the term Gadamer uses to refer to the manners in which different interpretations are made possible and effected only because of our prior involvement in, and understanding of, particular historical 'traditions', that is to say our inescapable historical and social situatedness.

3 Scheler recognises both 'positive' and 'negative' instances of 'fellow feeling', since some associative experiences might induce feelings of, for example, revelling in another's pain. It is an open question whether the many documented instances of the sealers' deliberate cruelty are carried out simply because they recognise 
Scheler, of course, was primarily referring to a fellow feeling towards other humans, to which he accords a 'special value' (70) as and when this fellow feeling extends, as he thinks it should, from individual encounters with Other humans to members of the human species in general, 'marking them off distinctly from the lower animals and from God' (69-70). In other words, while Scheler certainly thinks a similar fellow feeling 'can also be bestowed on animals' (70) (and even by animals on each other since he recognizes fellow feeling's evolutionary origins), he holds that this is qualitatively different from an active 'love of humanity' which involves the recognition of a 'quite specific and peculiar note of feeling' (70). He provides little justification for this view since the special status of humans was incontrovertible within his own philosophical milieu and clearly informed the ideal of Christian 'fellowship' that provided the backdrop for his life and work. But leaving Scheler's 'personalism' aside for the moment (see below), what is crucial here is his recognition of the ways in which 'fellow feeling' can, and often does, grow to include a wider community of significance while not neglecting the importance of the phenomenal experience of the individual case that initially instigates such emotional involvements. As Scheler says:

once benevolence has gained its impetus from pure fellow feeling, it can, by its own activity, enlarge the scope of the latter to an unlimited extent; for the experience gained in active well-doing, which proceeds from love only, and not from the essential passivity of fellow feeling, has the effect of continually increasing the range of objects accessible to fellow feeling. But this does not alter the fact that fellow feeling in general, as a felt intentional act, is a necessary condition for the possible emergence of benevolence. (70)

Scheler's ideas might then help make links between the phenomenological appearances of significant Others and the recognition of wider ethical and ecological constituencies. In actively attending to the (perhaps unexpected) elicitation of ethical feelings invoked by the seal's manifestation we also open ourselves to other (potentially unlimited) ethical possibilities that flow within and can change the patterns of significance that constitute what matters to us.

But this is where it is so important to recognize how radically Scheler's approach contrasts with those formal moralities often adopted by mainstream environmental ethics. The mode of abstraction that characterizes these approaches entirely overshadows the phenomenal role of 'fellow feeling' and the importance Scheler accords to 'active well-doing' and 'love'. These dominant

the seals' significance to protesters and want to hurt their feelings or whether they too, despite their claims to the contrary, recognise the seal pup as a significant Other, but one towards which they act in extraordinarily sadistic ways. 
approaches focus primarily on providing logical (necessary and sufficient) criteria for 'moral considerability' (Goodpaster 325) which they usually expand into moral axiologies - that is, formal systems and hierarchies of values (Smith, Ethics of Place). That is to say, they initially try to define and demarcate those categories of 'beings' that can justifiably be deemed to be morally significant Others, from that 'stuff' and those 'things' which logically cannot and are thereby reduced to being, at best, of merely instrumental value to the 'beings' that really (ethically) matter. On this view, for example, soil micro-organisms might simply be part of the stuff in which significant beings such as, say, moles or groundhogs live: they are means to these significant creatures' ends.

What this formal, analytic and legislative approach effectively does, however subtly or unsubtly, is divide the world into two supposedly fundamental moral and ontological categories, those with and those without formal moral standing'beings' or 'things', 'subjects' or 'objects', 'animate' or 'inanimate' and so ondepending on where and why a line is drawn. There are numerous examples in the early literature of environmental ethics of this formal bipartisan approach (Attfield; Taylor). Such systems prosper because they seem to provide abstract and supposedly universally applicable criteria, rationales and definitions that can be applied to situations by those not themselves intimately (that is to say personally, emotionally and phenomenologically) concerned in any particular case. In other words, they fit with the requirements of modern social, economic and governmental systems (Smith, Ethics of Place). ${ }^{4}$ For example, they might generate bureaucratic and legalistic criteria that could be used to distinguish between those kinds of things that can, and those beings that should not, be used as mere commodities, or beings that might be deemed to have 'rights', and so on. These systems can also be nested within each other to provide fine-tuning while still retaining this apparent logical universality - a given system might recognise that consciousness, for example, is a special case of sentience, which is in turn a special case of animate life, with each successive level requiring additional degrees of ethical attention.

Of course, a cynic might argue that such refinements also serve to qualify or even completely undermine the initial egalitarianism posited amongst members of the morally considerable. Just as in Orwell's Animal Farm, where 'all animals are equal but some animals are more equal than others' (112), some classes of beings remain more significant than others, although this significance is now apportioned in terms of various universally applied sets of criteria based in formal properties attributed to those entities. And, rather bizarrely for an environmental ethic, the paradigmatic model for moral attention at the centre

4 This was the basis of Scheler's critique that contemporary humanitarianism did not 'value the personal act of love from man to man, but primarily the impersonal institution of welfare' (Scheler qtd in Schneck 64, original emphasis). 
of these nested circles is invariably an abstraction of a specifically human being (Smith, Letting in the Jungle). ${ }^{5}$ Nonetheless, those employing this formal approach might justifiably argue that it can sometimes serve to expand the circle of beings generally regarded as morally considerable (Singer). Indeed, its argumentative force sometimes compels those convinced by its logic and its premises to recognise that even beings they continue to find aesthetically unattractive, repellent, or dangerous might still be morally considerable - not only relatively cute seal pups, groundhogs or moles, but snakes, snails, earthworms, or even micro-organisms depending, of course, on the formal criteria employed.

There is, though, something deeply unsatisfying about such approaches, and not because the very inclusion of vilified species might be regarded by some as indicative of a faulty logic, nor because such arguments are susceptible to commonly employed forms of 'slippery slope' arguments that push their bipartisan boundaries out into regions of ridicule. Should we really have to concern ourselves, the critic asks, about the mistreatment of nematodes, the eradication of bacteria, or the thousands of invertebrates killed every time we dig the vegetable garden? Well perhaps we should. But it is not really their overly-inclusive and contradictory consequences that constitute the main problem with such formal approaches. Rather it lies in their abstract and reductive form of argument and the very attempt to legislate the remit of (environmental) ethics and pre-determine (fix) the patterns of significance and significant associations. To extend our previous metaphor, these systems transform the earthly percolation of ethical flows into impervious concrete-lined drains and controlled irrigation schemes. Perhaps another way of saying this is that these formal systems fail to take seriously the ecology and phenomenology of our relations with the more-than-human world.

Ecologically, they fail to address complex relations of inter-dependence, whether in terms of competition, symbiosis, parasitism, mutualism, commensalism, or difficulties in even identifying individual 'beings', exemplified by the Glomeromycota, when speaking about 'entities' like ecosystems, forests or soils. They over-simplify or ignore the role of evolution, the importance of relative scarcity, biodiversity, and innumerable other factors, including the immense variety of ways that human practices interact with the world to give rise to specific concerns. To the extent that they do address such issues they risk tying themselves in elaborate conceptual knots that retain only the semblance of a

5 For example, Johnson suggests moral considerability is a matter of possessing interests. Many entities, some very unlike humans, have such interests. However Johnson also postulates a hierarchy of 'lower' and 'higher' beings suggesting that, although we ought not to 'step on ants just for the fun of it' those individuals 'higher up the scale merit more individual consideration. Sentience, preferences, and rationality would give us indications of greater moral significance' (200) and so, although he admits we may never find 'any entirely adequate formula for determining moral priorities' (200) he nonetheless understands ethics precisely as the formal elucidation of just such criteria. 
rigorous logic while actually appealing to one partisan intuition after another (Smith, Letting in the Jungle). In short, such abstract models pay insufficient attention to the ecological (and the hermeneutic) contexts composing the world, contexts which can and do affect our ethical responses.

Phenomenologically, although these systems must ultimately be reliant upon actual ethical experience - on someone, somewhere, actually having felt noninstrumental concern for Others - they operate on the basis of a supposedly impartial and unfeeling abstract logic that is meant to take precedence over, or even entirely replace, our actual phenomenal experiences. That is to say, while they may provide a rationale for extending moral considerability, they do so only at the cost of severely limiting the acceptable mode of such extension (to formal criteria) and severing moral considerations from actual value-feelings which are then made subject to abstract (context-free) rules and principles. As Joas argues, from the formal perspective it is as if 'we first produced a purely cognitive relation to objects of knowledge, in order then to direct feelings towards the objects so constituted' (88). The philosopher decides that we are justified in having any ethical feelings concerning a seal or an earthworm if and only if it possesses the requisite character.

This formalism strives to control and order any suspiciously different ethical inclinations, ignoring, where possible, those actual value-feelings which threaten to introduce a chaotic instability into systems of moral governance. The formal rationality that restricts and replaces value-feelings is awarded a spurious (bureaucratic) neutrality, precisely to the extent that it has been stripped of any and all such feelings. Ironically, one might say that, however well-intentioned, formalism's misrepresentation and elision of ecological and phenomenological concerns actually embodies the deficiencies of the ecologically destructive social forms an environmental ethics often needs to critique (Smith, Ethics of Place). And this is not just my opinion. Despite his anthropocentrism, Scheler goes much further. In a little noticed passage (first published in 1913) he links the attitude underlying modern moral formalism with modernism's approach towards the natural world:

This attitude I can only describe as a basic 'hostility' toward or 'distrust' of the given as such, a fear of the given as 'chaos', an anxiety - an attitude that can be expressed as 'the world outside me, nature within me'. 'Nature' is what is to be formed, to be organized, to be controlled; it is the 'hostile', the 'chaos' etc. Hence this attitude is the opposite of the love of the world, of trust, and loving devotion to the world. Strictly speaking, this attitude belongs only to modern times, which are permeated by ahatred of the world, a hostility toward the world, and a distrust of it, and by the consequence of this hatred: namely the limitless need to 'organize' and 'control', which this combination of apriorism 
and the theory of a 'forming', 'lawmaking' understanding (and a 'will of reason' that brings drives into an 'order') has psychologically caused. (Scheler, Formalism 67; original emphasis). ${ }^{6}$

By contrast, Scheler not only draws our attention back to what is phenomenologically given, an appearance imbued with value-feelings, but, as Joas remarks, also disparages the rationalistic assumption that

love makes one 'blind' rather than 'seeing', that therefore all genuine knowledge of the world can be based only on the most extreme restraint of emotional acts and on the simultaneous ignoring of the value differences of the objects, whose values are profoundly connected in the unity of experience with these experiences of acts. (Joas 88-9) ${ }^{7}$

This he scathingly describes as a 'specifically modern, bourgeois, judgement' (89).

These objections to traducing value-feelings informed Scheler's own sustained critique of formalism (and particularly Kantian formalism) in ethics (Scheler, Formalism). Thus, while he certainly shared Kant's view that ethics requires that we treat 'persons' as ends in themselves, and that every attempt to 'measure the goodness of the person in terms of the degree to which his accomplishments support an existing world of goods' (370) is unethical in the sense that it reduces them just to their instrumental role in maintaining a wider social (and, one might add, ecological) world, Scheler states we should also

ask whether a formalistic and rational ethics of laws does not also degrade the person (although in a different manner from that of goods or purposes) by virtue of its subordination of the person to an impersonal nomos under whose domination he can become a person only through obedience. (370; original emphasis)

This philosophical traducement is doubly degrading both to the 'giver' and 'receiver' of ethical attention. First, because it changes the nature of ethics from that of a phenomenology of fellow feeling, love, or concern for another, into a matter of exercising a will (gladly) to comply with rules, to do one's duty. ${ }^{8}$ Second, because these rules do not concern themselves with any person as such but only with the abstract qualities persons in general are supposed to embody. As Schneck argues:

6 It should be noted that Scheler's concern is to critique the way Kant combines and conflates formalism with an understanding of what constitutes the a priori, not to criticise apriorism per se (see below).

7 The passage Joas is referring to is in Scheler's essay 'Love and Knowledge' (Feeling 147).

8 This hardly does justice to Scheler's subtle interrogation of Kant's work. But as Scheler points out, this emphasis on formalistic rule-following leads to an 'almost unbelievable change in meaning [.... whereby the biblical call to] "Love God above all and your neighbour as yourself" has now become "Strive to like obeying God's commandments and fulfilling your duties to your neighbour"' (Formalism 226). 
In dutifully considering all 'persons' as formally identical in regard to their essential nature, the other is understood as less than the full person he is. ... Scheler's revelation of the essential non-objectivity of the other opens wide vistas of possibility for ethics, morality, social philosophy and political theory [...where] each person is afforded treatment appropriate to the incomparably unique dignity of her personhood. (61)

A non-formal ecological ethics would then presumably open the possibility of attending lovingly to what is phenomenologically given in and by the 'natural' world, to what appears as significant, and to the percolation (through partially pre-figured patterns of significance and the exercise of an active benevolence) of further ethical associations. But this still leaves many questions about the relations between phenomenal appearance and ethical significance, and the problems ecology would have with reducing ethics to a concern with 'personhood'.

\section{Scheler, Levinas and Ethical Significance}

Perhaps now we can begin to see how an 'ethics of appearance' might provide an alternative understanding of our ecological relations. Both moral formalism and Scheler's phenomenology agree that ethical relations are irreducible to instrumental approaches. However, they differ radically in terms of how entities come to be regarded as ethically significant. Scheler deems moral formalism deficient in terms of: a) its lack of attention to the phenomenology of valuefeelings (the actual experience of concern, fellow feeling or love for the Other); b) its unethical reduction of the Other's unique being to a formal and formulaic abstraction; and c) because, by extension, formalism also envisages the wider ethical community in these same terms, as a social arrangement constitutionally dependent upon these same formal abstractions rather than as, more fully, an ethical community constituted through mutual appearances, fellow feelings and associative significances. The key ecological question then is how Scheler's alternative, phenomenological approach might translate into an understanding of ethical relations within a community of more-than-human Others. But to approach this requires a more detailed exposition of the meaning of 'appearance', 'significance' and 'fellow feeling' which clearly, ecologically speaking, cannot be limited to Other 'persons' or people in general.

Here we might begin by noting certain similarities between (and similar humanistic limitations to) Scheler's ethics and those of Emmanuel Levinas. As is well known, Levinas understands ethics as a disruptive event, a significant happening that intervenes in our self-interested concerns. This event is initiated and sustained by what he terms an encounter with the 'face' of the Other (Levinas, Totality; Levinas, Thinking). Although this ethical event might 
indeed be incident upon the appearance of someone's actual face in front of us, Levinas also uses examples of someone's gestures, a greeting, a form of address, and so on. In other words the face is Levinas' term for whatever aspect of another person reveals her in her singularity as being so very different from, and so irreducible to, what our self-interested preoccupations might make of her (for example, in terms of fulfilling what we need or in terms of what she can do for us). The face is the revelation of that person as an ethically significant being, an epiphany that also simultaneously calls us to face up to our ethical responsibilities towards them, responsibilities that, to be ethical, involve respecting their irreducible difference from us. And part of this responsibility then would also be not to subsume them under pre-conceived categories that reduce them to abstractions, types, or formal categories, since these can only limit and distort their singularity. That is to say, Levinas' ethics, like Scheler's, is non-formal.

However, despite his indebtedness (like Scheler) to Husserl's phenomenology, Levinas sometimes denies that his ethics is phenomenological at all in the sense that he regards the face as always more than (indeed 'otherwise' than) just its phenomenal appearance in the world. The face is irreducible to what someone looks like, for example, their eye colour, the line of their mouth, the wave of their hair-and more than that present(ed) within the phenomenal world. The ethical relationship is not an intentional relation to an appearance as such, rather its significance in an ethical sense lies behind or beyond these appearances even as ethics is elicited by them. Ethically speaking, the face is not an object in the phenomenal world but (to use Levinas' phrase) 'beyond being'. In other words, the ethical relation is not, and cannot be, just a relation to an 'intentional object' in what Levinas understands as the usual phenomenological sense, because an ethical relation is precisely one that does not 'objectify' the Other. Rather, the phenomenal appearance of the face is to be understood as an opening on ethical possibilities, a call to responsibility for an Other who transcends their appearance, who is more than, and irreducible to, that which is phenomenologically disclosed. The face addresses us as a 'visitation' (Levinas, Humanism 31), as a 'coming from behind one's appearance, behind one's form' (31).

So, for Levinas, the Other is not reducible to their instrumental value to us, nor to their formal status, nor to their phenomenal appearance as an intentional 'object' of our concern. Nor is their significance reducible to a pre-given interpretation of their worldly and historical significance. That is to say, the Other disrupts not only our self-interested orientations and our superficial relations to 'things' around us, but also the hermeneutic situation we currently inhabit because she is the bearer of her own significance: 
The Other not only comes to us from a [hermeneutic] context but signifies by itself, without that mediation. The cultural signification that is in a way revealed, and reveals, horizontally; that reveals itself from the historical world to which it belongs; that, as phenomenology expresses it, reveals the horizons of this world; this mundane signification is disturbed and upset by another presence abstract (or more exactly absolute), non-integrated into the world. That presence consists in making an entry. (Levinas, Humanism 31)

Levinas' concern here is to avoid any kind of phenomenological and hermeneutic reduction of the Other that might, however distantly, parallel formalistic reductions by limiting their significance to that of their allocated place in the (phenomenal/cultural) world. The appearance of the Other shifts the ground on which we stand. There is a sense in which the Other always calls us out of the world with which we are familiar to insist that there is more, infinitely more, than initially appears to be the case, more than we know, see, or understand. Levinas' perspective provides us with an incredibly evocative and subtle understanding of the ethical event as the appearing significance of an Other that immediately transcends that appearance. This understanding seems quite compatible with, and in some respects to deepen, Scheler's position. For Scheler too fellow-feeling is where 'self-love, self-centred choice, solipsism and egoism are first overcome' (Scheler in Schneck, 63) ${ }^{9}$ and fellow-feeling is not a matter of the sympathetic reproduction of another's feelings in a form of imitation or identification, not a matter of 'feeling with', but of having 'it given to us that the other has an individual self distinct from our own, and that we can never fully comprehend this individual self' and this experience is 'given for us in expressive phenomena - again not by inference, but directly, as a sort of primary "perception"' (Scheler, Feeling 50).

This is certainly not the place to develop a detailed comparison between Scheler's and Levinas' philosophies, although it is remarkable how little academic attention seems to have been paid to any such comparison (but see Barber), and Levinas' own comments on Scheler are few and far between. However, from the perspective of a prospective ecological ethics, there are important differences between them. As already noted, Scheler is much more willing to recognise the evolutionary emergence of fellow feeling, whereas Levinas proceeds from a perspective that hardly seems to recognize the natural world's existence at all. And although both limit their ethical concerns to human Others, Levinas does

9 Strictly speaking, for Scheler fellow feeling is a 'higher', qualitatively different level of 'sympathy' developing from more basic forms of sympathy such as unconscious emotional identification [Einsgefühl], and the sharing of vicarious feelings [Nachgefühl]. In its positive (ethical) aspect, fellow feeling too develops further into what Scheler considers the still higher form of Christian love. By contrast, for Levinas ethics initially precedes any possibility of self-concern whatsoever, since self-awareness (awareness of oneself as a self) only comes through prior experience of the Other. This is why ethics is referred to as 'First Philosophy'. 
this on the basis of a largely unreflective and absolute metaphysical presumption that the ethical depth of the face is uniquely human - a presumption that has received criticism even by those who recognise Levinas' importance (Derrida; Llewelyn, Middle Voice; Llewelyn, Obsessed; Wood; Smith, Worldly (In) Difference).

Ironically, despite the whole anti-formalist thrust of his ethics, Levinas seems to fall back into an ethical formalism precisely where he deems it necessary to draw a line between human and non-human beings. One of the few occasions on which he approaches the possibility of ethics crossing the human/animal divide occurs in his famous discussion of Bobby, the dog who, for a few weeks, visited the Nazi slave-labour Camp in which he was incarcerated. Bobby, unlike the camp's guards, continued to relate to the camp's Jewish inmates as if they were human beings, greeting them with delighted barking and even offering them a 'semblance' of respect. And yet, despite appearances, Levinas is actually unwilling to conclude that Bobby is either behaving ethically, or could himself be the kind of being that could elicit ethical responsibilities. As Clark notes: "The most telling irony is that, in qualifying his claim that Bobby is the "last Kantian in Nazi Germany" on the grounds that he lacks "the brains necessary to universalize maxims and drives" Levinas almost exactly reproduces Kant's estimations of animals' (65). What is even more telling from our current perspective is that Levinas qualifies Bobby's ethical status on formal Kantian grounds! As Llewelyn notes, the door opening on an ethical community would 'seem to be slammed in Bobby's face, assuming he has one' (Obsessed 242; my emphasis). Here Levinas falls back into exactly the kind of generalized humanitarianism that Scheler is scathingly critical of, especially in his book Ressentiment.

Although Scheler often seems equally determined to maintain the special status of humans, his recognition of evolutionary affinities makes any absolute distinction much more precarious. The fact that fellow feeling entails the recognition of an Other's psychic life, for example, still allows the possibility that some animals may be so recognized. Indeed, in places, as Schneck notes, Scheler goes much further and explicitly refers to the values of a Franciscan view of nature that suggests 'the possibility of a fraternity between person and nature' (69). In Scheler's own words:

What is really new and unusual in St. Francis' emotional relationship to Nature, is that natural objects and processes take on an expressive significance of their own, without any parabolic reference to man or human relationships generally. (Scheler qtd in Schneck 68) 
One might say, in Levinasian terms, that for Scheler these natural 'objects' and 'processes' can also be experienced and understood as bearers of their own ethical significance. Here Scheler seems to come very close indeed to the kind of understanding that an ecological ethics requires.

What are we to take from this? For those open to such possibilities, and on occasion even for those like Levinas who consider themselves absolutely closed to them, more-than-human beings come face to face with us in ways that reveal the ethical limits of a formal humanism. Like the seal pup, their appearance as bearers of their own ethical significance elicits our concerns. Whether dog, seal, or woodland flower, these entities present us with an existence understood as being an 'end in itself', that is, of being irreducible to its role in a world composed only of our own self-interests. Such ethical events are, in many respects, beyond our conscious control (although we can sometimes choose to heed or ignore their repercussions). They happen to us even though the patterns of our previous existence certainly create allowances that enable their occurrence. Such appearances are the way of the world and also reveal something of the limits of our phenomenal worlds - the horizons that facilitate but also limit our capacity to behold what lies right before us or under our very feet.

Appearances matter. But, as we are aware even in everyday life, there is more to the world than that which appears to us. Only the most idealist form of anthropocentrism could possibly think that, for example, the new species of nematodes located in that Scottish soil sprang into 'existence' at the moment of their discovery by Sourhope's scientists: only by defining existence as existence as experienced by and for human being(s) could this possibly be the case. The worms surely inhabited Sourhope's soils before they ever attracted our notice even though the kinds of notice we give to them to some extent shapes the worms' significance to us, making them appear in a certain light (specifically, as objects on a very un-ecological microscope stage).

Ethics, however, is a particular mode of attending and responding to the beings that transcend, yet are nonetheless made manifest through, their appearances. To reiterate: an ethical relation is not just a response to appearance as such but to the singular ${ }^{10}$ being 'behind/beyond' (even if elicited by) that appearance. Furthermore, this awareness of a singular Other can, and quite frequently does, offer an opening, through the re-arrangement and challenge to the pre-

10 Singular here does not mean easily definable as, for example, being a particular physically bounded and defined individual; it connotes the realisation of a certain uniqueness and irreducibility, the impossibility of positing some kind of formal essence or identity. 
existing patterns of significance it helps constitute, of the existence of yet more beings that are not necessarily 'sensationally' apparent to me at all. It might, for example, even recompose the ways in which I relate to the earth beneath me.

To be clear: this does not mean that every aspect of nature we experience will affect us in this way or even that we have to value nature as a whole ethically, but it does provide another way of thinking about nature, one that draws on Heidegger's interpretation of ancient Greek philosophy. Here nature is itself understood as physis, the continual unfolding of existence into the phenomenal world of appearances. In Heidegger's terms (which seem peculiarly apt for our present purposes given our interest in soil) physis is that 'process' whereby the 'Earth' worlds, that is to say, the process whereby what exists becomes manifest, appears and takes on significance to us within our phenomenal world.

Physis is the self-revealing Earth pushing up into the phenomenal world. 'The world is founded on the Earth and the Earth thrusts up into the world' (Heidegger qtd in Haar 13), like a flower appears sprouting from the soil. There is always and continually an unfolding into the (phenomenal) world that also, when attended to in its singularity, introduces its own significance, and yet the Earth is never fully exposed or explicable, indeed even as it reveals itself in one way it also withdraws and closes in on itself. We might say that the Earth is 'reserved', not in the sense of being a 'resource' - an instrumental stockpile for human use, or like a hotel room that can be reserved for later occupancy-but in the sense that another person may act 'reservedly'. That is to say, that while what is manifested can touch us (physically and emotionally) it cannot be fully grasped in its infinite depth. As Haar puts it:

Opacity in Earth is powerful, but it must manifest itself. Thus the weight of the stone or the particular radiance of colours are revealed as modes of what is obviously present but unexplorable. ... Earth possesses a secret ground that resists every elucidation and that does not yield to the violence of an ex-plication or ex-position. One must acquiesce to its unopenable dimension if one does not want to destroy it. It must show itself as what it holds in reserve. (57)

In terms of ecological ethics, Earth might be regarded as Heidegger's name for the much more pervasive and much more-than-human depth beyond the worldly 'sur-face' presented to us. In this sense, ecological ethics might be understood as an un-selfish 'benevolence' initiated through 'fellow-feeling' in 'the event of the face of the Earth' (physis), and as the subsequent significant appearance of a community that can include 'soils, waters, plants and animals, or collectively, the land'. And if we think about nature in this way, then it becomes obvious 
that only an arrogant anthropocentrism would assume that there is more hidden about the existence of another individual human being than about all of morethan-human nature in its myriad forms.

\section{Cypripedium: Phenomenology Down to Earth}

Many miles to the South of Sourhope, in English limestone country, a plant appears from the early summer earth amongst the open slopes' rocks. Its large 'showy' flower on top of a tall green stalk has four maroon lanceolate 'petals' (technically perianths) surrounding a central yellow pouch-shaped feature that, viewed closely, gives it its name - the Lady's Slipper Orchid (Cypripedium calceolus). Its beauty explains its rarity, for this was, for a long while, the single remaining wild Lady's Slipper Orchid left in Britain (although there are wild European populations), the rest having long ago been lost to acquisitive collectors. Its very location remains a guarded secret. This same plant has flowered year on year, since the 1930's, a visible protrusion pushing up from the earth that shelters the plant's rhizomes which would otherwise remain hidden and unknown below the soil surface.

The flower's appearance in the phenomenal world is an event. But what kind of (ecological and ethical) significance might it have? If someone, struck by its beauty, picked that flower spike, took it home and placed it in a vase to admire, then all they seem to have concerned themselves with is its phenomenological appearance as an intentional object, some 'thing' desired in order to brighten a room, a souvenir of a day's rambling, to provide an unusual talking point, and so on. Their relationship is, although aesthetic, largely instrumental. They are not likely to be concerned with what has been left behind of the plant in the soil, or the result of picking that flower on the plant as a whole, let alone on the survival of Lady's Slipper Orchids in general or effects on the wider ecological community. An orchid collector, of course, may try to dig up the entire plant and spend many hours tending to its needs, but again, it seems that what matters here is the plant's ability to add a rare example to his collection, his relation to it is possessive, selfish.

How might this plant appear within the context of an ecological ethics? Imagine a passing walker about to lop off its flower with a casual swing of her walking stick. The plant's appearance and its precarious situation, like that of the seal pup discussed earlier, might manifest itself in such a way as to draw those open to such possibilities out of their self-possessed concerns and motivate them to intervene on the plant's behalf. But while certain aspects of the plant, like its spectacular flowers, certainly draw our attention, its ethical appeal (and our willingness to act) is not limited by or dependent upon its membership of any particular formal category or even to its being the sole wild representative of 
a purportedly uniquely British population (which would, of course require a very specific form of taxonomic pre-understanding). This is not to say that our response is uninfluenced by our hermeneutic situation, but to notice that, although no experience is ever context free, the plant also makes an entry into the phenomenal world as a carrier of its own significance in a Levinasian sense. Similarly, the ethical aspects of this event are marked by a concern that goes beyond its mere appearances, beyond an understanding of the flower as an intentional 'object'. To paraphrase Scheler, this plant is initially experienced in a kind of primary perception as being distinct from us but also as a being that is never fully comprehensible.

And, of course, this orchid is not easily defined. The showy flowers, only apparent for such a short period of the year, are only the tip of the iceberg. Its hidden subsoil rhizomes are also intimately conjoined, in ways that are poorly understood, with very specific taxonomical groups of mycorrhizal fungi. Indeed, the orchid's existence is inseparable from its mutual association with these fungi: 'Mycorrizal infection is a prerequisite for the germination and growth of all orchid seeds in the wild' (Shefferson et al. 614). The adult plant too may continue to be dependent on fungal-produced resources. Yet, despite many years of study the fungi themselves remain 'notoriously cryptic' (614) even though these particular relations may be the key factor determining the orchid's distribution. This in turn might suggest that there is also something special about the composition of the microscopic soil community in this place where Cypripedium calceolus retains its fragile foothold. ${ }^{11}$

But this does not mean that we need to treat the other members of the soil community instrumentally, as just that which facilitates the orchid's flowering. The orchid's appearance can also shift the patterns of our ethical responses and responsibilities more widely. Ethics flows through the landscape as we attend to it. What had been, perhaps, a rather uninteresting rocky slope begins to take on new significance as we become open to wider possibilities of other aspects of this place and other members of this community appear in our world. Crossing the ground before us a mole pushes its difficult way through the shallow earth: turning over a rock insects and centipedes scuttle for cover through white tangles of plant roots never before exposed to direct sunlight. And although so many of the entities that compose the soil beneath us remain invisible and non-individuated, in attending to what does appear we also intuit something of the inter-connected multitudes that continually escape our purview. As

11 This plant has now been self-fertilised by hand and seedlings have been grown in Kew Garden's laboratories for re-introduction to a number of sites where the plant is known to have grown in the past (Ramsey). 
with Levinas' ethics, an ecological ethics does not just concern itself with appearances, although, as Scheler argues, appearances and the felt act of fellow feeling are a necessary condition for the possible emergence of any ethics.

What appears in the openness of a loving (ethical, non-selfish and noninstrumental) attention, what is un-concealed (a-letheia) as carrying its own unexpected significance, also serves to indicate the Earth's reserve, its opacity, its concealing (lethe). An ecological ethics concerns itself with the ways in which the Earth shows itself as what it holds in reserve, with the way in which the surface of the soil is also an indication of its hidden depths and its un-explicated associations.

The Earth is, in Heidegger's terms, 'that which shelters in coming forth' (Heidegger qtd in Haar 57), and the earth that is this soil shelters hosts of phenomenal worlds that are irreducible, and to a large extent inaccessible, to our own (Uexküll). Indeed the living ecological community might be understood phenomenologically as composed of irreducible mutual appearances between various beings, each to the others (Smith, Against Ecological Sovereignty). The ecology of ethics lies precisely in not isolating individuals from this background as intentional objects or as members of formal categories, but in appreciating the not entirely comprehensible ways in which these individuals also constitute a part of a community of myriad beings which appear to each other in all kinds of ways, as commensual, as mutualistic, as parasite, as prey, as resources, as coevolved and evolving beings. Some are rare, some common; some specialized, some generalist; some crucial to the whole community's survival, some hardly at all. As and when we concern ourselves with these communities and attend to some of these inter-connections we open different ethical possibilities.

We can never hold all of this together abstractly as some cognitively ordered system constantly before our mind (or committed to a computer's memory). Rather, part of what it is to be a living being capable of ethical feelings and valuations is to be able to hold these felt values in reserve, releasing them in the face of certain (often unexpected) events, the origins of which we can never fully comprehend. And these events (if ethical) are never limited only to what appears as an intentional object. They realize something of the depth behind what faces us and simultaneously open possibilities for ethics to overflow along these hermeneutically and ecologically informed, but only partly pre-figured channels as and when our active involvement, our concerned attention, our love for the world comes to the surface as Others appear and disappear.

Attending to the natural world we come to realize that ecology matters. And an ecological ethics recognises that it matters even if it cannot always explicate how and why it matters. And what could matter more than the life-sustaining earth itself? 
What appears to us is not all that appears. What has significance in its appearance to us inevitably has different significance to others and a significance that overflows to Others. What appears in this world is not all there is to the Earth. And an ethical experience of the event of such appearances already attends to this Earthly infinity, which, like the self-revealing/self-concealing soil, underlies and grounds our temporarily finite phenomenal world, our all too short life on its surface.

Mick Smith is Associate Professor and Queen's National Scholar at Queen's University, Canada. He is the author or editor of several books on issues in environmental philosophy, including The Ethics of Tourism Development (2003), and An Ethics of Place: Radical Ecology, Postmodernity and Social Theory (2001).

\section{Works Cited}

Barber, Michael D. Guardian of Dialogue: Max Scheler's Phenomenology, Sociology of Knowledge and Philosophy of Love. Lewisburg: Bucknell UP, 1993.

Callicott, J. Baird. Beyond the Land Ethic: More Essays in Environmental Philosophy. Albany NY: SUNY Press, 1999.

Clark, David. 'On Being "the Last Kantian in Nazi Germany": Dwelling with Animals after Levinas.' Post-Modernism and the Ethical Subject. Ed. Barbara Gabriel and Suzan Ilcan. Montreal: McGill-Queen's UP, 2004.

Derrida, Jacques. 'Eating Well or the Calculation of the Subject: An Interview with Jacques Derrida with Jean-Luc Nancy.' Who Comes After the Subject. Ed. Eduardo Cadavera. London: Routledge, 1991.

Fitter, A. H. 'Darkness Visible: Reflections on Underground Ecology.' Journal of Ecology 93 (2005): 231-243.

Gadamer, Hans Georg. Truth and Method. New York: Continuum, 1998.

Goodpaster, Kenneth. 'On being morally considerable.' Journal of Philosophy 75 (1975): 308-325.

Haar, Michel. The Song of the Earth: Heidegger and the Grounds of the History of Being. Bloomington: Indiana UP, 1993.

Hyams, Edward. Soil and Civilisation. London: Thames and Hudson, 1952. 
Jackson, Wes, Wendell Berry and Bruce Colman. Meeting the Expectations of the Land: Essays in Sustainable Agriculture and Stewardship. San Francisco: North Point Press, 1984.

Joas, Hans. The Genesis of Values. Cambridge: Polity, 2000.

Johnson, Lawrence E. A Morally Deep World: An Essay on Moral Significance and Environmental Ethics. Cambridge: Cambridge UP, 1991.

Kropotkin, Peter. Mutual Aid: A Factor of Evolution. London: William Heinemann, 1907.

Leopold, Aldo. A Sand County Almanac and Sketches Here and There. Oxford: Oxford UP, 1968.

Levinas, Emmanuel. Entre Nous: Thinking of the Other. London: Athlone Press, 1998.

—. Humanism of the Other Urbana \& Chicago: University of Illinois Press, 2003.

—. Totality and Infinity. Dordrecht: Kluwer, 1991.

Llewelyn, John. 'Am I Obsessed by Bobby? (Humanism of the Other Animal.' ReReading Levinas. Ed. Robert Bernasconi and Simon Critchley. Bloomington: Indiana UP, 1991.

- The Middle Voice of Ecological Conscience: A Chiasmic Reading of Responsibility in the Neighbourhood of Levinas, Heidegger and Others. New York: St. Martin's Press, 1991.

Mowat, Farley. Sea of Slaughter. Toronto: McClelland and Stewart, 1984.

Orwell, George. Animal Farm. New York: Harcourt, Brace and Company, 1946.

Ponting, Clive. A Green History of the World. London: Sinclair-Stevenson, 1991.

Ramsey, Margaret M. 'Re-establishment of lady's slipper orchid (Cypripedium calceolus L.) in Britain.' Botanical Journal of the Linnaean Society 126 (1998): 173-181.

Shefferson, Richard P., Michael Weis, Thu Kull and D. Lee Taylors. 'High specificity generally categorizes mycorrizal association in rare lady's slipper orchid-genus Cypripedium.' Molecular Ecology 14 (2005): 613-626.

Scheler, Max. 'Fellow Feeling, Benevolence, Forms and Kinds of Love.' On Feeling, Valuing, Knowing. Chicago: U of Chicago P, 1993. 
Australian Humanities Review - Issue 50

- Formalism in Ethics and Non-Formal Ethics of Values. Evanston: Northwestern UP. 1973.

—. Ressentiment. Milwaukee: Marquette UP, 2007.

Schneck, Stephen Frederick. Person and Polis: Max Scheler's Personalism as Political Theory. Albany NY: SUNY Press, 1987.

Singer, Peter. The Expanding Circle: Ethics and Sociobiology. Oxford: Clarendon Press, 1981.

Smith, Mick. Against Ecological Sovereignty Minneapolis: University of Minnesota Press, forthcoming 2011.

-. An Ethics of Place: Radical Ecology, Postmodernity, and Social Theory. Albany NY: SUNY, 2001.

—. 'Letting in the Jungle.' Journal of Applied Philosophy 8 (1991): 145-154.

-. 'Worldly (In)Difference and Ecological Ethics: Iris Murdoch and Emmanuel Levinas.' Environmental Ethics 29 (2007): 23-41.

Uexküll, Jacob von and Georg Kriszat. 'A Stroll Through the Worlds of Animals and Men.' Instinctive Behaviour. Ed. Claire Schiller. New York: International Universities P, 1957.

Wood, David. 'Comment ne pas manger.' Animal Others: On Ethics, Ontology, and Animal Life. Ed. H. Peter Steeves. Albany NY: SUNY, 1999.

Worster, Donald. Dust Bowl: The Southern Plains in the 1930's. Oxford: Oxford UP, 1979. 